\title{
Selected Bibliography of Michael Ondaatje's Texts and Studies about Michael Ondaatje's Texts
}

\author{
Steven Tötösy de Zepetnek \\ University of Halle-Wittenberg
}

Follow this and additional works at: https://docs.lib.purdue.edu/clcweb

C.

Part of the Comparative Literature Commons, and the Critical and Cultural Studies Commons

Dedicated to the dissemination of scholarly and professional information, Purdue University Press selects, develops, and distributes quality resources in several key subject areas for which its parent university is famous, including business, technology, health, veterinary medicine, and other selected disciplines in the humanities and sciences.

CLCWeb: Comparative Literature and Culture, the peer-reviewed, full-text, and open-access learned journal in the humanities and social sciences, publishes new scholarship following tenets of the discipline of comparative literature and the field of cultural studies designated as "comparative cultural studies." Publications in the journal are indexed in the Annual Bibliography of English Language and Literature (Chadwyck-Healey), the Arts and Humanities Citation Index (Thomson Reuters ISI), the Humanities Index (Wilson), Humanities International Complete (EBSCO), the International Bibliography of the Modern Language Association of America, and Scopus (Elsevier). The journal is affiliated with the Purdue University Press monograph series of Books in Comparative Cultural Studies. Contact: <clcweb@purdue.edu>

\section{Recommended Citation}

Tötösy de Zepetnek, Steven. "Selected Bibliography of Michael Ondaatje's Texts and Studies about Michael Ondaatje's Texts." CLCWeb: Comparative Literature and Culture 6.3 (2004): <https://doi.org/10.7771/1481-4374.1244>

The above text, published by Purdue University Press @Purdue University, has been downloaded 2072 times as of $11 /$ 07/19. Note: the download counts of the journal's material are since Issue 9.1 (March 2007), since the journal's format in pdf (instead of in html 1999-2007).

This document has been made available through Purdue e-Pubs, a service of the Purdue University Libraries. Please contact epubs@purdue.edu for additional information.

This is an Open Access journal. This means that it uses a funding model that does not charge readers or their institutions for access. Readers may freely read, download, copy, distribute, print, search, or link to the full texts of articles. This journal is covered under the CC BY-NC-ND license. 


\title{
PURDUE
}

UNIVERSITY PRESS <http://www.thepress.purdue.edu>

\section{CLCWeb: Comparative Literature and Culture}

ISSN 1481-4374 <http://docs.lib.purdue.edu/clcweb> Purdue University Press @Purdue University

CLCWeb: Comparative Literature and Culture, the peer-reviewed, full-text, and open-access learned journal in the humanities and social sciences, publishes new scholarship following tenets of the discipline of comparative literature and the field of cultural studies designated as "comparative cultural studies." In addition to the publication of articles, the journal publishes review articles of scholarly books and publishes research material in its Library Series. Publications in the journal are indexed in the Annual Bibliography of English Language and Literature (Chadwyck-Healey), the Arts and Humanities Citation Index (Thomson Reuters ISI), the Humanities Index (Wilson), Humanities International Complete (EBSCO), the International Bibliography of the Modern Langua-ge Association of America, and Scopus (Elsevier). The journal is affiliated with the Purdue University Press monog-raph series of Books in Comparative Cultural Studies. Contact: <clcweb@purdue.edu>

\author{
CLCWeb Volume 7 Issue 4 (December 2005) Article 9 \\ Steven Tötösy de Zepetnek, \\ "Imre Kertész's Nobel Prize, Public Discourse, and the Media" \\ <http://docs.lib.purdue.edu/clcweb/vol7/iss4/9> \\ Contents of CLCWeb: Comparative Literature and Culture 7.4 (2005) \\ Thematic Issue Media and Communication Studies at the University of Halle-Wittenberg \\ Edited by Reinhold Viehoff \\ <http://docs.lib.purdue.edu/clcweb/vol7/iss4/>
}

Abstract: Steven Tötösy de Zepetnek, in his paper, "Imre Kertész's Nobel Prize, Public Discourse, and the Media," discusses aspects of media coverage in German-, Hungarian-, and Englishlanguage newspapers and magazines of the 2002 Nobel Prize in Literature, awarded to Imre Kertész. The perspective of Tötösy's analysis is to gauge the importance and impact of media coverage comparatively in the three cultural and media landscapes. Based on selected examples from newspapers and magazines with an international scope, Tötösy argues that the reception of Kertész's Nobel Prize suggests the convergence of the media (as the message) and the contents of the message within public discourse, resulting in Kertész's role as a public intellectual despite his reluctance to assume this role. Tötösy demonstrates that the media discourse reveals significant differences in the reception of the prize, pointing to different stages in democratic values in the context of the relevance of the Holocaust today. In addition, the media reception reveals how far a particular society accepts (Germany, the USA, and Canada) or rejects (Hungary) the historical relevance of Kertész's work as unique in the literature of the Holocaust. 


\section{Steven TÖTÖSY de ZEPETNEK}

\section{Imre Kertész's Nobel Prize, Public Discourse, and the Media}

In this paper, I discuss aspects of media coverage in German-, Hungarian-, and English-language newspapers and magazines of the 2002 Nobel Prize in Literature awarded to Imre Kertész. The perspective of my analysis is to gauge the importance and impact of media coverage in the three cultural and media landscapes comparatively. Attention to the processes and impact of media coverage of cultural products is of interest because of its obvious importance in the process of canonization, including book sales and general cultural, social, and political discourse (for an example of statistics of book sales after the award in Hungary and Germany, see H.Gy.-T.K.; Young). In particular, what interests me in Kertész's reception in the media are aspects of the convergences of the media and the contents of the message within public discourse, resulting in Kertész's role as a public intellectual. And this is not a given since Kertész pronounces repeatedly that he does not consider himself a public intellectual, while at the same time his works themselves and virtually all media items concerned with his work (or with him personally) he received, as well as his own words in interviews are contextualized in public discourse with special reference to the social responsibility of the writer per se, implicitly or explicitly. The reason for this, I propose, is the latent and since 1989 baffling explicit anti-Semitism with its parallel conservative-nationalist sentiment and, indeed, "program" of culture, apparent in public discourse, as well as -- in a more sophisticated manner -- in the policies and pronouncements of government such as the 1998-2002 government led by Viktor Orbán in Hungary. I should like to note that the publicly displayed antiSemitism in today's Hungary remains in Europe as well as in North America at best downplayed, as I experience(d) repeatedly in both Europe and North America (Canada and the US).

The reception of Kertész's work in his native and "literary" country, Hungary, in contrast to his position and reception where he feels at home intellectually, namely Germany, contextualizes and locates his own media statements and the public discourse in general in a political and ideological momentum. Kertész, I believe, is a public intellectual malgré lui and thus he is of great significance in the context of the above-mentioned problematic of Hungary, Central Europe, and, indeed, of the European Union, with regard to latent and currently explicit anti-Semitism and ethnic essentialism in Hungary: Comparatively, it is here where the media play a crucial role and where their impact is acutely discernable. Of course, the finding itself that Kertész, despite his reservations, is a public intellectual is no particular insight. What is interesting and worthy of study is, however, the description of the factors and processes of the controversy surrounding Kertész's Nobel Prize in Hungary in its relationship with the media elsewhere, precisely because of the shrill and sharp anti-Semitic and nationalist discourse present in the country (on this, see Gerö, Varga, and Vince; Marsovszky; Young). In addition, the media reception of the Nobel Prize in the case of a minor language and literature may be of interest to those working in literary as well as in media studies. An important issue -- while not discussed or reflected in the media, is, nevertheless, the "unwritability" of the Holocaust in fiction with regard to Kertész's texts: It appears that most general readers and, indeed, the general public, finds Adorno's dictum about the impossibility of poetry after the Holocaust the status quo, still. Although some -- including scholars -- would argue that fictional literature about the Holocaust is possible and even desirable and that Adorno's dictum would be a matter not applicable any more, the verdict is not out. Important authors and thinkers such as Elie Wiesel, George Steiner, or Michal Borwicz have stated in forceful terms that "there is no such thing as a literature of the Holocaust, nor can there be" (Wiesel qtd. in Felman 4; see also Taterka 117). Kertész's work in world literature is established with the Nobel Prize. However, as we know, the majority of writers who receive the Nobel Prize, while thus established in the canon, do not maintain visibility or a readership. In fact, most Nobel Laureates disappear from the landscape of reading shortly after receiving the award and remain, as well, little studied in scholarship. In the case of Kertész, this to-be-expected "disappearance" is the more acute because he writes in Hungarian, a minor language and a minor culture (I do not intend rehash the argument that Hungarian is a most difficult language, that it is un-categorizable and of unclear origins, and that it does not belong to the Indo-European family of languages, etc., but I would like to say that there is something true to these arguments, that is, how the language, because of the reasons mentioned, remains by definition marginal). I understand the Nobel Prize for Kertész as an award based on the particularity and specificity of his work, namely, the description of the terror in and the horrors of the twentieth century, the human condition of that century. I would like to add here that in comparison with the importance of the Laureate's texts, among incisive writers in Hungary today, there is an author who deserves our attention, Péter Nádas, an author who writes about the universal human condition with thematics and a narrative in his fiction, which transcend any particularity yet represent perhaps more eloquently linguistically, thematically, and narratively the best of literature of today anywhere. However, Nádas, too, suffers the same problem as Kertész, namely being a writer in a minor literature and minor culture with all all the drawbacks that go with that position. Other Hungarian writers of high currency are at best writers with a provincial or period flavor, such as Péter Esterházy -- who received, among other prizes, in 2004 the coveted German Friedenspreis -- and whose importance and popularity are based on his playing with a curious Central European type of irony and word play and on his passé status of an enfant terrible, or György Konrád, who is taken, mistakenly, for a writer of literature when, in fact, in my opinion he 
is a public intellectual who excels in essay writing -- but not as a writer of fiction, or the poet Endre Kukorelly, who, similarly to Esterházy, was important before and shortly after the fall of "real socialism" in 1989 because of the politico-cultural impact and period-location of his writing. To use another example, the highly acclaimed novel of László Márton, Árnyas föutca (1999), gives me the impression of an author who wants to be clever: The narrative structure of his novel is not particularly innovative except, perhaps, in Hungarian. It is a copy (or adaptation) of the Memento idea (or, and I am not facetious, of the film Ground Hog Day with Bill Murray). While the topic of Márton's book, dealing with anti-Semitism in Hungary before and after the war, is, of course, an important one for Hungary and in Hungarian literature, as literature in an international context it is not particularly impressive: Kertész's work is. I would like to add here, as a footnote: When it comes to innovation in Hungarian literature since the Second World War, the first and still best postmodern text is László Kemenes Géfin's Son of the White Stag (Fehérlófia) series of novels -the first volume of which was published in 1978 in Montréal, as a representative text of diaspora/exile literature; and, unfortunately, even today, sixteen years after the demise of communism in Hungary, Hungarian scholarship pays no attention to the work of Kemenes Géfin, which neglect, in turn, is rooted in the same essentialist ideology why Kertész's work is not accepted in Hungary by many... (on Kemenes Géfin, see Tötösy, "Some Examples"; Comparative Literature).

Imre Kertész -- resident of Budapest and Berlin and citizen of Hungary -- received the 2002 Nobel Prize for Literature in October of that year (for a bibliography of Kertész's work and studies about his work, see Tötösy, "A Bibliography"

<http://clcwebjournal.lib.purdue.edu/library/imrekerteszbibliography(totosy).html>): The Swedish Academy's choice came as a surprise to many and in various ways observers of literary and culture affairs, including many scholars, were taken unawares. In particular, the English-speaking world, including the US, knew and still knows little to nothing about Kertész and his work. For example, the MLA: Modern Language Association of America, the principal US-American organization of scholars working in the humanities and of academic institutions in the humanities, was unable to find a US-American expert who would field queries about the author (personal information). USAmerican and Canadian newspapers in print and on the world wide web contain scant and samesource information (the relatively large number of items on Kertész's Nobel Prize on the web, for example, are more often thank not of the same information drawn on the same source; on this, see also Young). The cavalier and sloppy attitude towards minor languages such as Hungarian prevails even with the Swedish Academy: In the first version of the official web site of the Swedish Academy about the new awardees, Nobel Prize in Literature: Laureates at

<http://www.nobel.se/literature/laureates/index.html>, the material about Kertész contained several errors in the spelling of names and in titles of books (see Tötösy de Zepetnek "And the 2002 Nobel Prize" <http://clcwebjournal.lib.purdue.edu/clcweb03-1/totosy03.html>). My brief analysis of the print media with regard to Kertész's Nobel Prize is based on a selection of items in German-, Hungarian-, and English-language newspapers and magazines, as well as some items on the world wide web. The method of sampling I use is "judgement sampling," an extension of convenience sampling, within the main category of the non-probability method of sampling. Thus, while my selection is by no means representative, it is an acceptable sample from a number of cultureoriented canonical newspapers with reports about and discussions of Kertész's Nobel Prize. Also, as my samples are from canonical newspapers I believe they allow for gauging public opinion. It is the general impression of the contents of the selected items that provide us with a gauge of the divergent qualities of Kertész's media presence and, by extension from the tone and language of the coverage, the hypothetical importance of media coverage of Kertész's Nobel Prize. In Germanlanguage media, Kertész and his work have been discussed prominently and positively. This is not surprising considering the fact that it was in Germany where Kertész's work received the most widespread and positive attention and it was the German committee for the nomination of authors for the Nobel Prize that proposed Kertész for 2002. In Iris Radisch's 2002 interview with Kertész in the weekly Die Zeit, the interview covers Kertész's personal as well as literature- and writingrelated perspectives about love, the Holocaust, Central Europe, Hungary, etc. Kertész's views are given well-guided exposure and his thoughts on various matters are stimulating, even if at times surprising. For example, Kertész defends German author Martin Walser's right as a writer to depict in his novel a Jewish literary critic in a negative and disturbing manner and Walser -- according to Kertész -- has the right to do so because as a writer he should be allowed to dislike this particular critic who happens to be Jewish (the interviewer's question relates to the much discussed Walser and Reich-Ranicki affair about the former's novel, Tod eines Kritikers (Marcel Reich-Ranicki is one of Germany's prominent literary critics, whose function as a public intellectual is significant). Kertész's opinion is of course that of a writer whose writing has been censored enough, and for long enough, so that this determines his permissive view pertaining to the freedom of expression.

The reasons for his view, as Kertész himself explains in the interview, would not stand up to scrutiny were he German (and, interestingly, no interview or other type of publication in the German-language media makes references or allusions to this matter). Nor would his view work for the North American (Canadian and US-American) reader either. Kertész says that Walser's disturbing depiction of a literary critic who happens to be a Jew whom the writer dislikes is allowable because "Why should it be anti-Semitic when this protagonist is unlikable? The protagonist is unlikable and by coincidence he is also Jewish. But in the first instance he is a critic. And most Jews are not critics" (all translations are mine unless noted otherwise) ("Warum soll es antisemitisch sein, 
wenn diese Romanfigur unansehnlich ist? Die Figur ist unsympatisch, und zufällig ist sie Jude. Aber in erster Linie ist sie Kritiker. Und die meisten Juden sind keine Kritiker") (Kertész qtd. in Radisch 45). The interviewer about the Walser affaire ends the conversation with the remark: "You are terrifyingly pluralistic" ("Sie sind erschreckend pluralistisch") (45). Indeed. And what is of importance here is the fact that what Kertész bases partially his argumentation on not to censor Walser, namely that "And most Jews are not critics" would of course work less in the US and, thus, there, the negative prototype of the Jew as a cultural standard of a Eurocentric world would make Walser's text clearly anti-Semitic. With regard to German-speaking countries, it is of course well known that in comparison with Canada or even the USA, the non-acceptance of the foreigner remains a serious problem (see, e.g., Bittner; Terwey). In spite of the importance of the Radisch interview in term of its wide-ranging thematics with regard to Kertész and his work, it did not find its way into either the Hungarian nor the Canadian or US-American media. Critics in Germanlanguage media paid close attention to the question of ethics and morality in the work of Kertész and its relationship with the Holocaust (see, e.g., Steinfeld; see also Adorján and Minkmar). With regard to this problematic, of significance is the recognition apparent in media items that Kertész's work is understood as non-moralizing, and this was described in comparison with the work of German Nobel Laureate Günter Grass (see Steinfeld). The non-moralizing aspect of Kertész's work is often developed when he is discussed in the context of other recent Nobel Laureates: The 2001 Nobel Laureate Gao Xingjian (see, e.g., Lee <http://docs.lib.purdue.edu/clcweb/vol5/iss1/4/>) as well as 2001 Nobel Laureate Naipul represent similar non-political and non-politicizing writing, where the task of a writer is understood as the writing of, foremost, litterrature pure. But this understanding of writers such as Gao and Naipul is misguided when we take into account the role of media. In the media, the work of Kertész and his persona are perceived clearly as "in-between" and contrary to the status quo, and in this regard he is similar to Gao, to Naipul, to Coeetze, to Jelinek (see, e.g, Bandhauer <http://docs.lib.purdue.edu/clcweb/vol7/iss1/1/>), all awardees in the last years. What the media presence of these authors shows is that while they themselves may point to the importance of a litterrature non engagée, in the media their writing is inevitably read and discussed often in political and ideological contexts. This locus of in-between and writing contrary appears to be evident in the case of the last several Nobel Laureates. For example, Gao is not accepted as a significant writer in the People's Republic of China (and resides in France) and his Nobel elicited almost nothing but objection there, Naipul often criticizes India in many of his novels (and lives in the United Kingdom), Kertész is considered in his native country by many a non-Hungarian (and resides in Berlin and Budapest), and the 2004 recipient of the Nobel Prize in Literature, Elfriede Jelinek, similarly to Kertész with regard to Hungary, criticizes Austria's reluctance to accept responsibility for the Holocaust, has been for years practically an "enemy of the state" (and she resides in München and Vienna).

A further perspective in the work of Kertész discussed in the media, that of its European-ness and, more precisely, its "Central European" cultural perspectives, are particularly noteworthy (on Kertész's Central European cultural location, see Tötösy de Zepetnek "And the 2002 Nobel Prize" <http://docs.lib.purdue.edu/clcweb/vol5/iss1/6/>). It was in the German media where Kertész's work and its award of the Nobel were discussed as a sign of Wiedervereinigung (reunification) in the context of the Ost-Erweiterung (expansion to the east) of the European Union (the irony of the term is of course not lost when thinking in terms of German history) (see, e.g., Müller). At the same time, some German critics with a more than usual knowledge of Central Europe and Hungary, propose that the Nobel Prize for Kertész could or would also mean that Hungarian culture is expanding to and penetrating the West with and through the international recognition of Kertész's work (see, e.g., Müller). The connection of Kertész's Nobel Prize with the May 2004 joining of Hungary with the European Union in media items would of course result in an improvement of latent cultural perceptions about "eastern" Europe. As I already indicated previously, an important aspect of Kertész's work, as well as of the last several Nobel Prizes, is the notion of periphery and inbetween-ness (there is a substantial amount of theoretical as well as applied work on the marginal and peripheral status of Central and East European cultures; see Tötösy, "Comparative Cultural Studies" <http://www.kakanien.ac.at/beitr/theorie/STotosy1.pdf>). What is interesting with Kertész in the context of the Nobel Prize is the fact that four consecutive laureates -- Gao, Naipaul, Kertész, and Jelinek -- are all "in-between" individuals, writers who live and write located in inbetween cultures. This aspect of Kertész and his work has been recognized in the media. For example, critic Uwe Schmidt, in his article "Poeta laureatus. Der Literaturnobelpreisträger 2002," focuses on this specific aspect of Kertész, namely his cultural Heimatlosigkeit, but which is to be understood as a construct of culturality that the author has developed to exist in in-between spaces, times, and cultures (see Schmidt). This aspect of existence in-between obtains higher importance in a situation when Kertész publishes in the Frankfurter Allgemeine Zeitung his essay "Ich bin der Spuk." The importance of Kertész's thought in the essay -- and the forum of its publication in a conservative newspaper -- lies in his argumentation to deprive meaning from the cliché that the root of identity resides in the mother tongue. This is the more important because Hungarian nationalism before and now argues for the tantamount importance of language for the maintenance of national identity: "The writer of the Holocaust is, indeed, in a difficult situation. ... that there is no language of the Holocaust and that there cannot be one. The survivor in Europe is able to tell his/her story only in a European language, yet this language is not his/her language nor is it the language of the nation from which he/she borrowed it for his/her writing" ("Der Schriftsteller des 
Holocaust ist also in der Tat in einer schwierigen Lage. ... daß es für den Holocaust keine Sprache gibt und keine Sprache geben kann. Der europäische Überlebende kann seine Leidensgeschichte nur in irgendeiner europäischen Sprache erzählen, doch diese Sprache ist nicht seine Sprache und auch nicht die der Nation, von der er sich die Sprache für seine Erzählung ausgeliehen hat") (Kertész, "Ich bin der Spuk" 46). A particularly sophisticated description of Kertész and the Nobel Prize is the article by Thomas Steinfeld in the Süddeutsche Zeitung, "Bescherung. Imre Kertész in Stockholm: Eine Selbstauskunft und keine." In the piece, Steinfeld analyses Kertész's acceptance speech and presents his opinion about both the writer as a person and his texts. Interesting is that Steinfeld accords Kertész an amicable personality that is tied to an intellectual sophistication worthy of the Nobel Prize. Steinfeld also proposes that the Swedish Academy and the audience at the acceptance speech did not, really, understand Kertész or his work. Steinfeld suggests that Kertész as an individual is deeply philosophical (in the context of understanding; on this, see Friedland) about the Holocaust and his own relationship with it, while at the same time in his work he comes to provoke an opposition -- his and in general -- to the postmodern notion that there is an author no more. Kertész argues, instead, for knowledge understood in the experience of the Holocaust. In Steinfeld's essay, the implicit and explicit criticism of the Swedish Academy and its not-fully understanding of the significance of Kertész's oeuvre is an exception in the otherwise positive accounts of Kertész's Nobel Prize in the German-language media.

A curious situation has occurred in the German media in relation to Kertész, after and since the 2003 war in Iraq, one that demonstrates ideological fault lines within German-language media. As Kertész states in an interview in the magazine Newsweek, "We need to define a European identity that loves America, because Europe stands in America's debt" (Kertész qtd. in Thiel 96). Consequently, Kertész is critical of the German and French stand on the war in Iraq. For obvious reasons, namely because Germany's objection to the US war on Iraq, the German media does not report explicitly Kertész's statements about his opposition to the German and French negation of US policies and actions. However, his criticism did become a media issue: At a high-profile conference, Day of German Unity: German Anti-Americanism and Eastern European Pro-Americanism, the official federal government celebration for the "Day of German Unity" on 3 October 2003 in Magdeburg, Kertész was one of the keynote speakers, where he objected to and criticized the German stand strenuously. In the Frankfurter Allgemeine Zeitung Kertész's views were described as follows: "Kertész complained about Europe's division over the Iraq War. It presumably reverted 'back to its old structures.' Suddenly the Iraqi dictator was able to let us forget who was a friend and who was an enemy. It came to 'ridiculous verbal battles' between supporters and opponents of the war. Kertész referred in this context to the fact that the Eastern European countries stood on the side of the United States and Great Britain. Poles and the Czechs were better able to remember Munich (1938) than most Western Europeans. Kertész also said that the fight against terrorism was a fight between good and evil, one that is just as important for Europe as it is for America, with, in his view, pacifism. Pacifism no answer to the challenge of terrorism, either" ("Tag der deutschen Einheit" 3). David Kaspar analyzes the response to Kertész in the German media thus: "Imre Kertész's criticism of Germany's Iraq policy is quoted by the German media, but not emphasized, and instead hidden in the texts of longer descriptions of the event. It is interesting to note that not a German publication, but the Swiss Neue Zürcher Zeitung printed the full speech of Imre Kertész. In contrast, US-American critics of President George W. Bush such as Michael Moore or Susan Sontag can usually easily publish in German newspapers and magazines" (Kaspar

<http://medienkritik.typepad.com/blog/netzeitung/>). I should like to note here that while the tone and amount of US-American critical discussions of US government decisions in US-American media right after 9/11 and right after the 2003 invasion of Iraq suggest self-censorship of the USAmerican media, in both instances this self-censorship has given way to the appearance of a large number of pro- and con-views, which can be seen, for example, in any issue of any day of the New York Times or the Washington Post. In contrast, in Germany, where Kertész's views have been always given ample latitude and exposure in the media, his view with regard to the 2003 Iraq war was given no attention beyond a few lines in the Frankfurter Allgemeine Zeitung. What this suggests is that in Germany, while cultural, historical, sociological, etc., as well as public discourse about and on the Holocaust are a given, this standard is not allowed to extend to a matter concerning current public opinion, such as the 2003 Iraq war. In other words, while there are instances of self-censorship in current US-American media, the same can be observed in German media. Obviously, these occurrences of limitations, while they do not pose a threat to free speech, do pose serious questions about the power of media when it selects and self-censors matters not deemed appropriate in a climate of divided public opinion.

Overall, my reading of the media response to Kertész's Nobel Prize in German-language print media is that his texts and the Nobel Prize are described with sophistication and more than the usual knowledge about Central Europe and Hungary. As a result, the media response to Kertész's Nobel Prize represents critics' and the public's continued interest in the author's work and underlines the importance of his work in the contexts of literature, ideology and history. While this importance is understandably in the context of Germany's attention to matters relating to the Holocaust, tangential attention in the media, such as with regard to the eastward expansion of the European Union, the question of committed literature versus literature for the sake of literature, or the question of in-between-ness as a postmodern condition suggest a social and political impact of Kertész and the Nobel Prize that is duly registered in German media discourse. As to the problem- 
atic of my interpretation with regard to the media reception of the Nobel Prize in Hungary, the German media appears to be unawares of the blatant anti-Semitic discourse in Hungary. To my knowledge, the first item about this appeared in the weekly Die Zeit in its 3 June 2004 issue, with an article entitled "Die versteckten Juden," with the explanatory paragraph below the title of the article: "Hungary is home of the fourth largest community of Jews in Europe. With the freedom came a newly acquired self assurance in the younger generation. Yet, if someone confesses to his/her Jewish faith, risks still today being vilified" ("Ungarn ist die Heimat der viertgrößten jüdischen Gemeide in Europa. Mit der Freiheit ist ein neues Selbstbewusstsein in der jungen Generation erwacht. Doch wer sich zu seinem Glauben bekannt, riskiert auch heute noch, angepöbelt zu werden") (Schneider 15). While the attention to the situation of Hungarian Jews in Die Zeit is clearly an important step for the recognition of the matter in Hungary, in my opinion the article itself is of a very tentative and accommodating tone. That is, the author of the article, Richard Chaim Schneider, while exploring some of the issues, does not appear to be aware of the seriousness of anti-Semitism and its discourse in the country. And, overall, the same can be stated about the US-American and Canadian media and their lack of attention to the situation in Hungary. USAmerican media reacted to the Nobel Prize in Literature awarded to Kertész similarly to the situation when Polish poet Wislawa Szymborska received the 1996 Nobel in Literature, with a resolute "Who?" The title of Stephen Kinzer's review, "America Yawns at Foreign Fiction" in the New York Times, says it all. Kinzer's review of the situation of foreign authors, gauged on the echo of Kertész's Nobel, is interesting also from a statistical point of view. Kinzer writes that "Readers in other developed countries still have appetites for translated literature. German publishers, for example, bought translation rights to 3,782 American books in 2002, while American publishers bought rights for only 150 books" (A1). And the media response was no different in Canada. In addition to the marked non-interest of the general public in foreign literature, critics whose interests would perhaps include the promotion of translated works are few. The reviews of Kertész after he received the Nobel show this clearly: Of the few reviews published in the US-American and Canadian media, most were by critics of Hungarian descent, such as the Columbia professor emeritus István Deák, who published an extended review of Kertész and his work in the New York Review of Books, or George Szirtes, who published the review "Nobel Laureate Who? Imre Kertesz, That's Who" in the journal Maisonneuve: Eclectic Curiosity (see at

<http://www.maisonneuve.org/index.php?\&page_id=12\&article_id=88>). While Kertész was an unknown writer even among scholars of literature, let alone to the general public in Canada and in the US before and when he received the Nobel, since then the moderate interest generated by the Nobel Prize has ebbed to a barely noticeable trickle and remains perhaps only among scholars interested in Holocaust literature (and where this interest includes Hungarian-language primary texts; the call for papers for the present volume on Kertész's work in the PMLA: Publications of the Modern Language Association of America and on several listserves resulted in moderate interest on the English-language landscape of scholarship: it would be unthinkable, in another case, to receive in total twenty-one papers for a volume on a Nobel Prize winner). Among the very few items in US-American print media on Kertész's Nobel, it is Stefan Thiel's one-page interview with Kertész, "A Voice of Conscience" in Newsweek that is the most comprehensive. Of particular interest to me is Thiel's question to Kertész about the currency of terrorism and the divergence of Europe and the USA. As introduced above, Kertész's response is one of mitigation between the two opposing positions -- and the Thiel interview took place before the invasion of Iraq -- where Kertész says: "We need to define a European identity that loves America, because Europe stands in America's debt" and continues with a clear and forceful warning that "We [Europeans] might be growing back together economically, but there are a lot of psychological traumas we haven't dealt with. The old nationalisms that exploded in the Balkan wars are a example of that. And Eastern Europe doesn't trust the EU, which waited much too long after 1989 to reach out. Back then we were all enthusiastic about a reunited Europe, and what happened? Instead we all watched powerlessly as Europe let genocide happen once again" (Kertész qtd. in Thiel 96). I read Kertész in Thiel's interview as Kertész's indictment of Europe, based on his epistemological, psychological, and historical understanding of western modernity as an era of totalitarian horrors and on his understanding and verdict about the response to these horrors by the United States. Together with his view that "let's not forget that America is built upon the most beautiful of Europe's ideals," Kertész as a writer and here as a public intellectual expressing hi views in the press comes through with a powerful message both Europe and the USA -- policy makers as well as the public -- could or ought to appropriate. Here, the medium is not only the message but the message is content without the medium....

In my selection of items from the Hungarian press I focus on pro-Kertész items because of the context and contexts the award in which his work is discussed and because anti- Kertész items are of lesser interest, owing to their un-differentiated and blatantly anti-Semitic and/or conservative nationalist ideologies (although, at the same time, these items are of course most important because of their existence per se; on the aspects of the conservative-nationalist and anti-Semitic reception of Kertész's Nobel, see Marsovszky; Young;). As I suggested previously, although publications -- either in content or with regard to their numbers -- of anti-Kertész items in Hungary did not reach and did not gather interest in German-, English-, or French-language media, what these items suggest is that anti-Semitism in Hungary exists to an unacceptable level today (see Marsovszky; Young). In the context of Hungary's joining the European Union in 2004, the level of antiSemitism that in public discourse in the media in Hungary ought receive due attention as an omi- 
nous situation that is unacceptable: The reception of the Kertész's Nobel Prize in the Hungarian media -- pro and con -- becomes a matter of importance for the European Union, de facto (and perhaps even de jure). Overall, the reception of the award in the Hungarian press is complicated to gauge because of the social and intellectual self-divide, increasingly so in the last several years, of the country into pro- and anti-Semitism that is played out in full force in the media (for a positive item in the Hungarian media, see also Böhm, Vári, Koltai, and Várnai; with regard to the situation of populist right-wing matters in Central and East Europe, see Chiantera-Stutte and Petö <http://docs.lib.purdue.edu/clcweb/vol5/iss4/2/>; re Hungary, see Marsovszky; Young). In the Hungarian media, Gáspár Miklós Tamás's article "Kertész Imre magyar író Nobel-díjas. Zsidó" ("Hungarian Writer Imre Kertész, Jew, Receives the Nobel Prize") published in the daily Magyar Hírlap on 11 October 2002 -- one day after the announcement of the prize by the Swedish Academy -- was the first article in the war of words and ideologies (see at

<http://www.magyarhirlap.hu/Archivum_cikk.php?cikk=57200\&archiv=1\&next=60>). Tamás -- a well-known liberal philosopher and, since 2004, a representative of Hungary in the European Parliament -- predicted in his article the coming onslaught of a national debate, which has played out and is still playing out two years after the award in Hungarian media. In newspapers and magazines with right-of-center or outright right-wing ideologies the award received brief but scathing criticism, as George Szirtes's states laconically, "The political resonance of Kertész's prize is shown by the way parts of the Hungarian press have treated it. Although the distinction of the Nobel Prize had long been sought and might have been wildly welcomed as an overdue recognition of Hungarian writing, the main nationalistic right-wing paper reduced the news to a paragraph" (Szirtes <http://www.maisonneuve.org/index.php?\&page_id=12\&article_id=88>).

Indeed, media resonance in Hungary to Kertész's Nobel has been controversial and divided along ideological lines (for discussions on the current situation of nationalism and anti-Semitism in Hungary, see, e.g., Gerö, Varga, and Vince; Ozsváth; Suleiman; Tötösy, "And the 2002"

<http://docs.lib.purdue.edu/clcweb/vol5/iss1/6/>; and the already referred to studies by Marsovszky; Young). The dividing lines are of course not simple but multi-level and multi-voiced, although I propose that in the anti-Kertész camp there are two -- at times overlapping and coinciding, at times not -- ideologies: One that is anti-Semitic of the first order and the other that is nationalistic in the best tradition of Hungarian self-referentiality, where the concept of and adherence to nation is understood as a co-referent of language, including literature. Here is one example: "Fatelessness is the work of a genius. Only, it is not Hungarian. Which is a problem, because Nobel Prize recipient Imre Kertész receives the Prize. In turn, for the literary canon this means that now he is the greatest Hungarian writer. He, who does not consider himself Hungarian" ("A Sorstalanság zseniális alkotás. Csak nem magyar. Ami azért baj, mert Kertész Imre nobeldíjas kap díjat. És ez a kánon szempontjából aztat jelenti, hogy mostantól Ö a legnagyobb magyar iró. Ö, aki nem tartja magát magyarnak") (Waltraute qtd. in Székely 7). The essentialist equation nation $=$ culture, and, in the case of Hungary, nation = language \& literature (this goes back to one of the greatest figures of Hungarian history, the nineteenth-century aristocrat István Széchenyi, who coined "it is in its language where the nation exists" ["nyelvében él a nemzet"], a credo of Hungarian nationalism ever since) has proponents also among pro-Kertész critics (see, e.g., Pallagi), although there are others who consider the award to be that of/for Kertész in the first instance and to be that of/for literature in the second, and then with the addition of "Hungarian" only as a last and accidental instance (see Bánó). Of course, the problem and unsavory in the opinion by the email correspondent "Waltraute" is the blanket assumption that Kertész himself would claim that he is not Hungarian and the correspondent's belief that a Hungarian can be of one type -- the essentialist type -- only. Unfortunately, this belief is shared by a substantial number of the population in today's Hungary.

An important item is the artiçle "Az eredendö történelmi bün" ("The Original Sin of History") in the culture magazine Kritika by Ákos Szilágy, who reads Kertész not as a Holocaust author but as an author of a post-Holocaust world which, in turn, is impregnated by and is based on the Holocaust understood as the human condition of modernity (as does Kertész himself). Szilágyi reads Kertész's texts as an interpretation of this human condition, the "mythology of nothingness" ("a semmi mitosza") as represented by the Holocaust (Szilágyi 7). And the world can exist only as a livable world if we recognize the universality of the Holocaust. Whether this view and opinion is in contradiction to the in many quarters accepted opinion that the Holocaust is unique in the history of humanity remains an open question, and further analysis of the Nobel Laureate's work is needed to come to an understanding of this problematic. Nevertheless, Szilágyi's analysis of Kertész's texts underlines what I propose to be the importance of the media reception of Kertész's works and the Nobel Prize, namely that Kertész and his work are unique because, despite their author's insistence on non-engagement, his merit is, precisely, the results of public discourse in the media about the un-speakability of the Holocaust in an innovative and until now un-explored way. This is the case especially in comparison with the majority of authors who write in fiction, in documentary, in autobiography, or in fictional autobiography, or who write about the Holocaust in the second generation of Holocaust victims or survivors. A further consequence of this public discourse in the media is the importance of the process from author to public intellectual per se, thus demonstrating the "power" of the media. Despite itself, there is poetry after the Holocaust, and Kertész shows us how in a new and innovative ways. Kertész's work is thus significant and needed not only as a text of literary, cultural, and social relevance, in the study of literature and culture, in Holo- 
caust studies, and in history: His work is an eternal mark in Western culture, along with Wiesel, Lévi, Borowski, Nyiszli, Ember, Frank, (the just discovered) Némirovsky, and so many others (for a survey of literary texts about the Holocaust including East European writers, see Várnai).

Note: The above article is an updated version of Steven Tötösy de Zepetnek, "Imre Kertész's Nobel Prize, Public Discourse, and the Media" in SPIEL: Siegener Periodicum zur Internationalen Empirischen Literaturwissenschaft 22.1 (2003): 183-94. and "Imre Kertész's Nobel Prize in Literature and the Print Media" in Imre Kertész and Holocaust Literature. Ed. Louise O. Vasvári and Steven Tötösy de Zepetnek. West Lafayette: Purdue UP, 2005. 232-46.

\section{Works Cited}

Adorján, Johanna, and Nils Minkmar. "Liebe ist das Wichtigste." Frankfurter Allgemeine Sonntagszeitung (13 Oktober 2002): 21.

Bandhauer, Andrea. "An Introduction to the Work of Elfriede Jelinek, Nobel Laureate in Literature 2004." CLCWeb: Comparative Literature and Culture 5.1 (2005):

<http://docs.lib.purdue.edu/clcweb/vol7/iss1/1/>

Bánó, András. "Kié az elismerés?" Blikk (12 October 2002): n.p.

Bittner, Jochen. "Deutschland: Wo jeder sich vor jedem fürchtet." Die Zeit 46 (7 November 2002): 10-11.

Böhm, Ágnes, György Vári, Nelli Koltai, and Pál Várnai. "Köszöntjük a Nobel-Díjas Kertész Imrét!" ("We Congratulate the Nobel Laureate Imre Kertész!"). Szombat 10 (2002): 5-17.

Chiantera-Stutte, Patricia, and Andrea Petö. "Cultures of Populism and the Political Right in Central Europe." CLCWeb: Comparative Literature and Culture 5.3 (2003): <http://docs.lib.purdue.edu/clcweb/vol5/iss $4 / 2 />$.

Deák, István. "Stranger in Hell." New York Review of Books (25 September 2003): 65-67.

Felman, Shoshana. "Camus' The Plague, or a Moment to Witnessing." Testimony: Crises of Witnessing in Literature, Psychoanalysis, and History. Ed. Shoshana Felman and Dori Laub. New York: Routledge, 1992. 93-119.

Friedland, Amos. "Imre Kertész, Hegel, and the Philosophy of Reconciliation." Imre Kertész and Holocaust Literature. Ed. Louise O. Vasvari and Steven Tötösy de Zepetnek. West Lafayette: Purdue UP, 2005. 51-64.

Gerö, András, László Varga, and Mátyás Vince. Anti-Semitic Discourse in Hungary in 2000.'Budapest: B'nai B'rith, 2001 .

Gerö, András, László Varga, and Mátyás Vince. Anti-Semitic Discourse in Hungary in 2001. Budapest: B'nai B'rith, 2002 .

H., Gy.-T.K. "Kelendőek lettek a Kertész-könyvek" ("Kertész Books have Become Sought After"). Napi Gazdaság (11 Oktober 2002): n.p.

Kaspar, David. "German Media Reject Charge of Anti-Americanism / Deutsche Medien weisen Vorwurf des Anti-A'merikanismus zurück." Davids Medienkritik (2004): <http://medienkritik.typepad.com/blog/netzeitung/>.

Kertész, Imre. Fatelessness. Trans. Tim Wilkinson. New York: Vintage, 2004.

Kertész, Imre. "Ich bin der Spuk." Trans. Kristin Schwamm. Frankfurter Allgemeine Zeitung 62 (14 March 2002): 46.

Kinzer, Stephen. "America Yawns at Foreign Fiction." The New York Times (26 July 2003): A17-19.

Lee, Mabel. "Nobel in Literature 2000 Gao Xingjian's Aesthetics of Fleeing." CLCWeb: Comparative Literature and Culture 5.1 (2003): <http://docs.lib.purdue.edu/clcweb/vol5/iss1/4/>.

Marsovszky, Magdalena. "Imre Kertész and Hungary Today." Imre Kertész and Holocaust Literature. Ed. Louise Ó. Vasvári and Steven Tötösy de Zepetnek. West Lafayette: Purdue UP, 2005. 148-61.

Marsovszky, Magdalena. "Imre Kertész -- einer von uns! Oder doch nicht? Kulturkampf und Identität in Ungarn." Europas Mitte, Mitteleuropa, europäische Identität? Geschichte, Literatur, Positionen. Ed. Barbara Breysach and Dorothee Rabe. Berlin: Logos, 2003. 137-53.

Marsovszky, Magdalena. "Der Antisemitismus in Ungarn. Nur Polit-Folklore?" haGalil.com: Culture \& News from Central Europe (2002): <http://antisemitismus.juden-in-europa.de/osteuropa/ungarn.htm>.

Müller, Lothar. "Eine Wiedervereinigung." Süddeutsche Zeitung (Feuilleton) (12-13 October 2002): 11.

Némirovsky, Irène. Suite française. Paris: Denoël, 2004

Nobel Prize in Literature, The: Laureates (2002): <http://www.nobel.se/literature/laureates/index.html>.

Ozsváth, Zsuzsanna. "Radnóti, Celan, and the Aesthetic Shifts in Central European Holocaust Poetry." Comparative Central European Culture. Ed. Steven Tötösy de Zepetnek. West Lafayette: Purdue UP, 2002. 5169.

Pallagi, Ferenc. "Tizezer perc" ("Ten Thousand Minutes"). Tallózó (17 October 2002): 2726.

Radisch, Iris. "Die Glückskatastrophe. ZEIT-Gespräch mit dem Nobelpresisträger Imre Kertész über Berlin, den Antisemitismus, das Geld und die Erlösung." Die Zeit 43 (17 Oktober 2002): 45-46.

Schmidt, Uwe. "Poeta laureatus." Thalia LiteraTouren Thalia Bücher (2002): n.p.

Schneider, Richard Chaim. "Die versteckten Juden." Die Zeit (3 June 2004): 15-18.

Steinfeld, Thomas. "Ein Steinchen für Sisyphos." Süddeutsche Zeitung (Feuilleton) (11 October 2002): 14.

Steinfeld, Thomas. "Bescherung." Süddeutsche Zeitung (Feuilleton) (9 Oktober 2002): 18.

Suleiman, Susan Rubin. "Central Europe, Jewish Family History, and Sunshine." Comparative Central European Culture. Ed. Steven Tötösy de Zepetnek. West Lafayette: Purdue UP, 2002. 169-88.

Szilágyi, Ákos. "Az eredendö történelmi bün" ("The Original Sin of History"). Kritika (February 2003): 4-8.

Székely, R. Julianna. "A Sorstalanság.... Igy írunk mi. (Idézetek az internetröl)" (Fateless.... And Thus We Write. [Quotations from the Internet]"). Vasárnapi Hírek (13 October 2002): 7.

Szirtes, George. "Nobel Laureate Who? Imre Kertesz, That's Who." Maisonneuve: Eclectic Curiosity 3 (2003):

<http://www. maisonneuve.org/index.php?\&page id=12\&article id=88>.

"Tag der deutschen Einheit." Frankfurter Allgemeine Zeitung (4 Ōctober 2003): 3.

Tamás, Gáspár Miklós. "Kertész Imre magyar író Nobel-dijas. Zsidó" ("Hungarian Writer Imre Kertész, Jew, Receives the Nobel Prize." Magyar Hírlap (11 October 2002):

<http://www. magyarhirlap. hu/Archivum cikk.php?cikk $=57200 \&$ archiv $=1$ \&next $=60>$.

Taterka, Thomas. Dante Deutsch. Studien zur Lagerliteratur. Berlin: Erich Schmidt, 1999.

Thiel, Stefan. "A Voice of Conscience." Newsweek (6 January 2003): 96.

Tötösy de Zepetnek, Steven. "Some Examples of Political Satire in Hungarian Exile Literature: Systemic Considerations." The Search for a New Alphabet: Literary Studies in a Changing World. Ed. Harald Hendrix, Joost Kloek, Sophie Levie, and Will van Peer. Amsterdam: John Benjamins, 1996. 250-55.

Tötösy de Zepetnek, Steven. Comparative Literature: Theory, Method, Application. Amsterdam: Rodopi, 1998. 
Tötösy de Zepetnek, Steven. "Comparative Cultural Studies and the Study of Central European Culture." Comparative Central European Culture. Ed. Steven Tötösy de Zepetnek. West Lafayette: Purdue UP, 2002. $1-32$

Tötösy de Zepetnek, Steven. "Comparative Cultural Studies and the Study of Central European Culture." Kakanien Revisited'(2003): <http://www.kakanien.ac.at/beitr/theorie/STotosy1.pdf>.

Tötösy de Zepetnek, Steven. "And the 2002 Nobel Prize for Literature Goes to Imre Kertész, Jew and Hungarian." CLCWeb: Comparative Literature and Culture 5.1 (2003):

$<$ http://docs.lib.purdue.edu/clcweb/vol5/iss1/6/>.

Tötösy de Zepetnek, Steven. "A Bibliography of Works by and about Imre Kertész, Nobel Laureate in Literature 2002." CLCWeb: Comparative Literature and Culture (Library) (2005):

<http://clcwebjournal.lib. purdue.edu/library/imrekerteszbibliography(totosy). html>.

Tötösy de Zepetnek, Steven. "A Bibliography of Imre Kertész's Oeuvre and Publications about His Work." Imre Kertész and Holocaust Literature. Ed. Louise O. Vasvári and Steven Tötösy de Zepetnek. West Lafayete: Purdue UP, 2005. 300-19.

Várnai, Paul. "Holocaust Literature and Imre Kertész." Imre Kertész and Holocaust Literature. Ed. Louise O. Vasvári and Steven Tötösy de Zepetnek. West Lafayette: Purdue UP, 2005. 247-57.

Young, Judy. "The Media and Imre Kertész's Nobel Prize in Literature." Imre Kertész and Holocaust Literature. Ed. Louise O. Vasvári and Steven Tötösy de Zepetnek. West Lafayette: Purdue UP, 2005. 271-85.

Author's profile: Steven Tötösy de Zepetnek teaches media and communication studies at the University of Halle-Wittenberg. His areas of research include literature and culture, theory and application in modern and contemporary European and North American fiction, diaspora, exile, and ethnic minority writing, media and communication studies, audience studies, postcolonial studies, film and literature, bibliographies, new media scholarship and knowledge management, and editing. He published recently the collected volumes Imre Kertész and Holocaust Literature (Ed., with Louise O. Vasvári, 2005) and Comparative Cultural Studies and Michael Ondaatje's Writing (2005). 